\title{
Climate Change Implications for Management and Use of Agricultural Biodiversity Resources in Africa
}

\author{
Pius Z. Yanda
}

Centre for Climate Change Studies, University of Dar Es Salaam, Tanzania

Copyright $@ 2015$ Horizon Research Publishing All rights reserved.

\begin{abstract}
This paper presents finding from a literature review linking climate change and biodiversity in the African context. It has become a reality that climate is changing and such changes are man-induced phenomena. Climate change is and will affect both natural and social systems including agricultural and biodiversity resources. In this regard, many of the genetic resources will become more threatened under changing climate, thus destabilize food ecosystems significantly. There is no doubt that with climate change, the value of genetic resources for food and agriculture will increase in the near future. This is because the diversity present in agricultural ecosystems constitutes a central element in the livelihoods of many rural communities. However, while agricultural biodiversity will be significantly affected by climate change it will also be an important element in the development of agricultural production strategies to meet the challenges of climate change. Genetic resources in agricultural sector will thus become crucial in developing adaptation strategies to confront climate change, so as to ensure the sustained increase in food production necessary to feed the world and ensure rural development. This paper is very cleared and explained with many bibliography references. All aspects of African agriculture and biodiversity are considered. I conclude that it is an excellent document to be accepted.
\end{abstract}

Keywords Africa, Climate Change, Impacts, Agriculture, Biodiversity and Management

\section{Introduction}

Agricultural biodiversity includes the variability among living organisms contributing to food and agriculture, including also the forestry and fisheries sectors. This concept includes diversity within species, between species and of ecosystems. While biodiversity for food and agriculture will be significantly affected by climate change, it will also be an important element in the development of production strategies to meet the challenges of climate change (FAO 2008). Agricultural biodiversity provides a number of benefits within production systems. These include benefits associated with production and productivity, agro-ecosystem function, and human well-being (FAO 2008). These services are mainly attained through the utilisation of agricultural lands for agricultural production (Smith et al. 2007).

Agriculture is an important sector in the economy of most developing countries in terms of its contribution to economic growth, employment and foreign exchange (Collier et al. 2008; Challinor et al. 2007) it is also interesting to justify this importance with African agriculture development details programme of African Union and NEPAD adopted in 2003 in Maputo in Mozambique by African's head of states. At present, $40 \%$ of the Earth's land surface is managed for cropland and pasture, and nearly $70 \%$ of people in developing countries live in rural areas where agriculture is the largest supporter of livelihoods ((Foley et al. 2005, FAO, 2004c; Easterlings et al. 2007).

The impacts of climate change on agriculture will be felt more in poor, geographically vulnerable nations with largely agrarian economies, mainly the East and Central Africa region. Tanzania is one such country where some 80 per cent of its workforce is in agriculture and, with climate change set to lower yields in key crops (Chambwera and MacGregory 2009; Deressa 2006). Climate change is expected to affect these large and physically diverse countries in Africa in a variety of ways. For example, temperatures in East Africa are expected to rise by between $2-4^{\circ} \mathrm{C}$ by 2100 , thus shifting agro-ecological zones (Easterling et al. 2007). The inter-annual, monthly and daily distribution of climate variables (e.g., temperature, radiation, and precipitation, water vapour pressure in the air and wind speed) affects a number of physical, chemical and biological processes that drive the productivity of agricultural, forestry and fisheries systems (e.g., Leff et al. 2004). Total seasonal precipitation as well as its pattern of variability are both of major importance for agricultural, pastoral and forestry systems (Olesen and Bindi 2002; Easterling et al. 2007).

This article is based on review of published literature that links climate change and agro-biodiversity. The focus is on how climate change will affect both negatively and positively agro-biodiversity and how agro-biodiversity could contribute to climate change adaptation. 


\section{Climate Change and Agricultural Biodiversity}

It is of great concern that climate change and variability will seriously affect agro-biodiversity (Brooks et al. 2005). The highest damages from climate change are predicted to be in the agricultural sector in sub- Saharan Africa. Agriculture is predicted to be especially vulnerable in this region because it already endures high heat and low precipitation, is a large fraction of the economy, and relies on relatively basic technologies (Pearce et al. 1996; McCarthy et al. 2001; Kurukulasuriya, and Mendelsohn 2006). Other related factors are postulated to be institutional and economic reforms linked to globalisation processes (e.g., removal of subsidies, increased import competition) which reduce the capacity of some farmers to respond to climate variability (O'Brien et al. 2004). Thus, efforts to reduce vulnerability and facilitate adaptation to climate change are influenced both positively and negatively by changes associated with globalisation (Eakin and Lemos 2006; Easterling et al. 2007). It is on these grounds that climate change is seen to be one of several factors that may affect global food production and genetic production in the near future (Reilly 1999).

Climate change is also likely to influence redistribution of weeds, insects, and other agricultural pests. This may pose greater demand for chemical pesticides. Warmer temperatures will also increase water demands for crop growth. In areas where increased water demand is not offset by additional rainfall or irrigation water supplies, climate change may further intensify the competition between growing urban, industrial, recreational, environmental, and agricultural users of water (Reilly 1999). The following sections provide detailed analysis of various impacts of climate change on agricultural biodiversity.

\subsection{Climate Change Impact on Crop Diversity}

Since most developing countries depend heavily on agriculture, the effects of global warming on croplands are likely to threaten both the welfare of the population and the economic development of the countries. Tropical regions in the developing world are particularly vulnerable to potential damage from environmental changes because the poor soils that cover large areas of these regions; and already have made much of the land unusable for agriculture (Houghton and others 1996 cited in Mendelson and Dinar 2005; IPCC 2007). Consequently, developing countries have grown increasingly concerned about the economic impact of climate change on agriculture (Watson et al. 1996, cited in Mendelsohn and Dinar 2005). There are concerns that small-scale farmers who have very little capital will not be able to pursue the new strategies that will be required to adapt to the changing climate (Mendelsohn and Dinar 2005; Easterling et al. 2007). Agronomic models of climate sensitivity indicate that higher temperatures are likely to be harmful in many developing countries where the climate is marginal, water is inadequate, and temperatures are high
(Rosenzweig and Parry 1994; Reilly et al. 1996 in Mendelsohn and Dinar, 2005). A further increase in temperatures will make many agricultural areas less productive and some completely unsuitable (Mendelsohn and Dinar 2005; Reilly 1999).

While agronomic literatures provide different insights on climate change implications on crop production, they all conclude that climatic factors most affecting crops are the intensity and duration of rainfall, the relationship between annual rainfall and potential evapo-transpiration, and the year-to-year variation in rainfall. For instance, the length of the growing season depends partly on rainfall, evaporation and temperature, partly on soil factors (mainly how much moisture gets into the soil and is retained) and partly on crop factors (the most important being the plant's rooting and maturing characteristics) (Machiara 2004). In addition, processes that determine crop yield under climate change are estimated to be the response of crops to mean temperature, the interaction between water stress and $\mathrm{CO}_{2}$, and the interaction between ozone and a range of environmental variables.

The major parameters that have being cited to be significant in the climate change dimension include the changes in temperature and rainfall patterns (both to averages and to the variability of rainfall), with many semi-arid parts of the developing world likely to becoming even hotter and dryer with even less predictable rainfall. These changes will both directly affect crop yields and ecosystem distributions and species ranges (Easterling et al. 2007). This will dramatically affect the livelihoods of many poor people, particularly through declining food security. Secondary impacts will likely include increases in urban food prices and greater problems with services such as water supply and sanitation (exacerbating pressures that rapid urbanization will bring) that affect the urban poor ( IISD 2003; Easterling 2007).

Direct and indirect effects of climate change on agriculture are estimated to be negative. Studies show that the overall predictability of weather and climate would decrease, making the day-to-day and medium-term planning of farm operations more difficult. Also, sea-level rise $(40 \mathrm{~cm}$ in the coming 100 years) would submerge some valuable coastal agricultural land ((Sombroek and Gommes 1996; IPCC 1992; 2007). Likewise, incidences of diseases and pests, especially alien ones could increase, and present (agro) ecological zones could shift in some cases over hundreds of kilometres horizontally, and hundreds of metres altitudinally. In this regards, some plants, especially trees, and animal species cannot follow in time, and that farming systems cannot adjust themselves in time. Other impacts include higher temperatures that would allow seasonally longer plant growth and crop growing in cool and mountainous areas, thus leading to increased cropping and production. In contrast, in already warm areas climate change can cause reduced productivity, and hence the imbalance of food production particularly in the developing countries (Sombroek and Gommes 1996; IPCC 1992, 2007; Collier et 
al. 2008).

The greatest risks are often estimated to be associated with increased soil loss through erosion. Soils, as a medium for plant growth, would be affected by increased temperatures that may lead to more decomposition of soil organic matter; and increased plant growth due to the carbon dioxide $\left(\mathrm{CO}_{2}\right)$ fertilization. However, this effect may cause other plant nutrients such as $\mathrm{N}$ and $\mathrm{P}$ to become in short supply; although other estimates show that $\mathrm{CO}_{2}$ increase would stimulate mycorrhizal activity (making soil phosphorus more easily available), and also biological nitrogen fixation (whether or not symbiotic) (Sombroek, W.G and Gommes, R 1996)

In addition to changes in precipitation and total water availability for irrigation, that directly affect agricultural production, changes in the pattern of water use by crop plants throughout the season may affect the outcome. Of special concern is the change in the physiological functioning of the vegetation as a consequence of the changed atmospheric composition (Van De Geijn and Goudriaan. 1996). Increased temperature would also affect the crop calendar in tropical regions (Abrol and Ingram 1996; IPCC 2007). In semi-arid regions and other agro-ecological zones where there is wide diurnal temperature variation, relatively small changes in mean annual temperatures could markedly increase the frequency of highest temperature injury (Abrol and Ingram 1996; IPCC 2002)

\section{2. $\mathrm{CO}_{2}$ Fertilization Effect}

Higher atmospheric $\mathrm{CO}_{2}$ concentration increases growth rates and water-use efficiency of crops and natural vegetation. The increased productivity is generally accompanied by more litter or crop residues, a greater total root mass and root exudation, increased mycorrhizal colonization and activity of other rhizosphere or soil micro-organisms, including symbiotic and root-zone $\mathrm{N}$, fixers (Brinkman R and Sombroek W.G 1996; IPCC 2002). The latter would have a positive effect on $\mathrm{N}$ supply to crops or vegetation.

The increased microbial and root activity in the soil would lead to increased rates of plant nutrient release (e.g., $\mathrm{K}, \mathrm{Mg}$, micronutrients) from weathering of soil minerals. Similarly, the mycorrhizal activity would lead to better phosphate uptake. These effects would be in synergy with better nutrient uptake by the more intensive root system due to higher atmospheric $\mathrm{CO}_{2}$ concentration. The greater microbial activity tends to increase the quantity of plant nutrients cycling through soil organisms. The increased production of root material (at similar temperatures) tends to raise soil organic matter content, which also entails the temporary immobilization and cycling of greater quantities of plant nutrients in the soil (Brinkman R and Sombroek W.G 1996). However, higher $\mathrm{C} / \mathrm{N}$ ratios in litter reported under high $\mathrm{CO}_{2}$ conditions, would entail slower decomposition and slower remobilization of the plant nutrients from the litter and uptake by the root mat, and would provide more time for incorporation into the soil by earthworms and termites ((Brinkman and Sombroek 1996).

Higher soil temperatures would counteract increases in 'stable' soil organic matter content but would further stimulate microbial activity. The consequently rapid increases in soil organic matter dynamics and soil micro-organisms may cause temporary competition for plant nutrients. These temporary effects have been reported as negative factors affecting plant response to elevated $\mathrm{CO}_{2}$. However, increased organic matter dynamics and microbial activity in soils are positive for the soil-plant system when $\mathrm{CO}_{2}$ concentrations rise gradually over decades, as currently and in the recent past (Brinkman R and Sombroek W.G 1996). This section is also clearly explained with bibliography references. But, it could be interesting to give some examples (quantity or rates) of advantages of $\mathrm{CO}_{2}$ fertilization effects on crops, plants and others.

\subsection{Effects of Rainfall on the Landscape}

Increased intensities of rainfall events and increased rainfall totals which are predicted to dominate in some areas under the changing climate would increase leaching rates in well-drained soils with high infiltration rates, and temporary flooding or water-saturation, hence reduced soil organic matter decomposition in level or depressional landscapes (Brinkman R and Sombroek, W.G 1996). This may affect a significant proportion of better soils in Sub-Saharan Africa. Such heavy rains would also give rise to greater amounts and frequency of runoff on soils in sloping terrain, with sedimentation down slope. Locally, there would be increased chances of mass movement in the form of landslides or mudflows in certain soft sedimentary materials (Brinkman R and Sombroek, W.G 1996). However, higher rainfall would be expected to lead to widespread increases in ground cover, and consequently better protection against runoff and erosion (Brinkman, R and Sombroek, W.G 1996; L. Hartwell Allen, JR; Jeff T. B; and KEN J. B, 1996). However, despite these possible negative effects of increased intensities of rainfall events, it should be noted that communities have been responding to such changes for years now. Example is given for the Matengo System in the Southern Tanzania which community derived soil and water conservation system that is capable of trapping eroded soil and surface run-off from the upper slopes of the landscape (Yanda et al, 2005).

\subsection{Genetic Resources for Food Production}

The 2005 Millennium Ecosystem Assessment estimated that by the end of this century, climate change will be the main driver of biodiversity loss. Along with predicting a higher risk of extinctions, temperature increases will impact ecosystem functioning, including those important for food supply. Increases in global average temperature exceeding $1.5-2.5^{\circ} \mathrm{C}$ and in concomitant atmospheric carbon dioxide concentrations will lead to major changes in ecosystem structure and function, species ecological interactions, and 
species geographical ranges, with predominantly negative consequences for biodiversity, and ecosystem goods and services such as water and food supply (IPCC,2001 \& 2007; FAO 2008). According to IPCC (2007), by 2100 the resilience of many ecosystems, agriculture in particular, (their ability to adapt naturally) is likely to be exceeded by an unprecedented combination of change in climate, associated disturbances such as flooding, drought, wildfire, insects, ocean acidification, and other global change drivers such as land-use change, pollution, over-exploitation of resources) (IPCC 2007). Smallholder and subsistence farmers; and pastoralists and fisher folk are likely to suffer complex and localized impacts of climate change (FAO 2008; Easterling, et al. 2007).

Climate change will affect the ecosystem services provided by agricultural biodiversity. This impact may be different for the different components of agricultural biodiversity. Also, there will be mismatches in response times to climate change between interacting species (plant and pest). For instance, certain genotypes will be favoured against others and communities within agro-ecosystems (FAO 2008). This means that there will be trophic decoupling of food webs and disruption of mutualism and evolutionary processes, leading to loss of functional biodiversity and to localized impacts in the delivery of ecosystem services such as lack of pollination, loss of soil biodiversity and capacity for nutrient cycling, or loss of natural biological control leading to potential new pest outbreaks. IPCC (2007) asserts that roughly 20 to 30 percent, varying from 1 percent to 80 percent among regional biotas of species assessed so far (in an unbiased sample), are likely to be at increasingly high risk of extinction as global mean temperature exceed 2 to $3^{\circ} \mathrm{C}$ above pre-industrial levels (Fischlin, A, 2007). Loss of biodiversity will affect food and agriculture, and may well lead to significant losses of genetic diversity within the species most important for food and agriculture. Thus, impact would be severe since the genetic resources concerned are the living material that local communities, breeders and researchers use to adapt to changing socio-economic needs and ecological challenges (FAO 2008).

Arguably, maintaining and using a wide basket of genetic diversity at a time of climate change will be an essential insurance policy for the food and agriculture sectors. With climate change, the value of genetic resources for food and agriculture will increase in the near future. Many of these resources will become more threatened, as global climate change will erode genetic diversity and destabilize food ecosystems significantly. The suitability and distributions of species and genotypes in food production systems will change greatly as well as the distribution in ecosystems of many wild relatives of species relevant to food and agriculture. Many rain-fed crops in tropical areas may approach their maximum temperature tolerance if temperature increases. An increase in temperature may also reduce the area suitable for some crop species in certain regions, while it may expand the areas in other regions.
Similar trends can be observed in animal husbandry, with some species substitution already occurring in some drought prone areas in Africa (camels substituting goats, sheep or cattle). Countries will increasingly depend on food species and genetic diversity from other countries and regions to adapt their food and agriculture. Interdependence among countries will increase as a result of climate change (FAO 2008). While climate change threatens the survival of agricultural biodiversity, there have been little efforts to develop integrated agricultural adaptation strategies to climate change (FAO 2008).

Given the anticipated negative effects of climate change on the genetic biodiversity, it is equally important to explore opportunities that come along with climate change. In this regard, some areas which were not favourable for given crops will have the right ecological condition for some crops to be grown. For example, much as high altitude areas will no longer be suitable for tea and coffee, they will be favourable for crops like beans and maize due to increased temperature.

\section{Agricultural Biodiversity for Climate Change Adaptation}

Adaptive capacity with respect to current climate is dynamic, and influenced by changes and availability of wealth, human capital, information and technology, material resources and infrastructure, and institutions and entitlements (Yohe and Tol, 2001; Eakin and Lemos, 2006; Seo and Mendelsohn 2006; Easterling et al. 2007). The production and dissemination of seasonal climate forecasts has improved the ability of many resource managers to anticipate and plan for climate variability, particularly in relation to ENSO, but with some limitations (Harrison, 2005; Easterling et al. 2007).

Fostering the ability to adapt to changing climate will involve improving the ability of agricultural systems to respond to generally changing and uncertain conditions largely through existing policy instruments such as support for agricultural research, trade policy, water management, and commodity program and pricing (Reilly 1999). In agro-ecosystems the choice of longer-duration cultivars or changes in cropping pattern could eliminate unproductive periods that might arise because of the shorter growth cycle of the main crop (Brinkman and Sombroek 1996).

Enhancing ecosystem services through use of agricultural biodiversity will be crucial, given that it contributes to adaptation, mitigation and resilience. Good management of agricultural biodiversity allows production systems to adapt to changing conditions while maintaining productivity. Enabling the sustainable use of agricultural biodiversity has a huge potential for developing win-win strategies with multiple benefits such as coping with climate change, conserving biodiversity and improving human well-being. Likewise, extreme climate events will increase disturbance of agro-ecosystems, which can be buffered through the sustainable use of agricultural biodiversity (FAO 2008). 
Table 1. Usefulness of Genetic Diversity in Adapting to Climate Change Impacts

\begin{tabular}{|c|c|c|c|c|c|}
\hline \multirow[t]{2}{*}{ Adaptation to } & \multicolumn{4}{|c|}{ Agricultural Biodiversity } & \multirow[t]{2}{*}{ Examples of Traits and Mgt Practices } \\
\hline & Animals & Plant & Forestry & Aquatic & \\
\hline $\begin{array}{c}\text { New Abiotic } \\
\text { Stress }\end{array}$ & $\mathrm{X}$ & $\mathrm{X}$ & $\mathrm{X}$ & $\mathrm{X}$ & 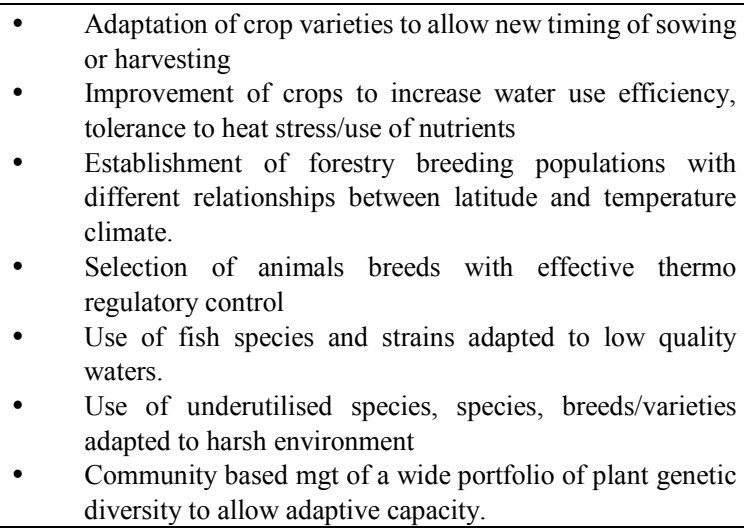 \\
\hline $\begin{array}{l}\text { New biotic } \\
\text { Stress }\end{array}$ & $\mathrm{X}$ & $\mathrm{X}$ & $\mathrm{X}$ & $\mathrm{X}$ & $\begin{array}{l}\text { - Use of disease-resistant cultivars, multilines or farmers' } \\
\text { composite mixtures to strengthen crop resilience and } \\
\text { resistant. } \\
\text { Enhancement of the resistance/tolerance to diseases by } \\
\text { management of animal genetic resources. } \\
\text { Use of diversification strategies to increase the number of } \\
\text { species and genetic diversity being farmed to reduce } \\
\text { vulnerability }\end{array}$ \\
\hline $\begin{array}{l}\text { Extreme } \\
\text { Climate } \\
\text { Events }\end{array}$ & & $\mathrm{X}$ & $\mathrm{X}$ & & $\begin{array}{l}\text { Use of genetic diversity of fire-tolerant forest species } \\
\text { Community conservation of local varieties adapted to cope } \\
\text { with extreme climatic events }\end{array}$ \\
\hline
\end{tabular}

Source: FAO 2008, 2007

The sustainable use of genetic resources for food and agriculture will be the foundation for many of the adaptation strategies required in food and agriculture. In order to adapt to climate change, plants and animals important for food security will need to adjust to abiotic changes such as heat, drought, floods and salinity. As climate change brings new pest and diseases, new resistances will be required for animal breeds, fish breeds and crop and forest varieties. Genetic diversity which is currently underutilized may become more attractive to farmers as a result of climate change. A summary of the usefulness of genetic diversity in food and agriculture in adapting to climate change impacts in production systems is summarised in Table 1

\subsection{Animal Genetic Resources}

It is important to note that livestock diversity adds resilience to agricultural production systems. However, human drivers of change in agricultural systems are leading to major and rapid loss of animal genetic diversity potentially putting more than one third of breeds at risk globally. This is particularly worrying as breed loss may lead to genetic erosion of important fitness and adaptation traits (FAO 2007). Temperature increase, with reduced precipitation in many regions, will result in reduction of livestock reproduction and production as a result of heat stress. Increases in the frequency of droughts, floods and disease epidemics will increase the risk of losing entire breeds and populations that have a limited geographic distribution. Increases in the price of feed, energy and water may force a shift to less intensive management systems, requiring improvement of local low-input low-output animal breeds (FAO 2008).

Controlling overgrazing through pasture improvement has a favourable impact on livestock productivity (greater income from the same number of livestock) and slows or halts desertification (environmental aspect). It also provides social security to the poorest people during extreme events such as drought (especially in Sub-Saharan Africa) (Smith P et al 2007). One effective strategy to control overgrazing is the prohibition of free grazing. However, the approaches need to take into account cultural and institutional contexts. Dryland and desert areas have the highest number of poor people (Millennium Ecosystem Assessment, 2005) and measures to halt overgrazing, coupled with improved livelihood options can help reduce poverty and achieve sustainability goals (Smith et al. 2007).

\subsection{Adaptation in Agricultural Systems}

Depending on the region and the available resources, options for adaptation range from relatively inexpensive changes, such as shifting planting dates or switching to an existing crop variety, to much more costly measures including the development of new crop varieties, increasing chemical and other inputs and irrigation systems (Rosenzweig and Tubiello 2007; Campbell et al 2009). Thus, diverse agricultural systems, incorporating new varieties of crops and crop diversification, are likely to be essential in maintaining food production under changing temperature 
and water conditions. Such agricultural systems are clearly dependent upon a range of crops, for which the maintenance of agro biodiversity is critical. 'Good practice' natural resource management, including water and soil conservation, is also likely to play a major role in agricultural adaptation, particularly in drylands. Agroforestry, intercropping food crops with tree stands, has been identified as a promising option to improve resilience of agricultural systems to climate change (Campbell et al. 2009). Options for adaptation in agriculture include: i) changes in the locations of cultivation (i.e. opening new areas for cultivation); ii) changes to the crops cultivated, including substitution by new crops, new varieties and crop diversification; and iii) changes to agricultural practice, including irrigation and soil management regimes and the use of agricultural inputs. Biodiversity plays an especially strong role in supporting the latter two options (Campbell et al 2009).

Within a given region, different crops are subject to different degrees of impact from current and anticipated climate changes (Lobell et al. 2008 cited in Campbell et al 2009). One major avenue for adaptation is the substitution of different crops more suited to changing and new conditions. Rice, maize, and wheat contribute roughly half of the calories currently consumed by the world's poor (Lobell et al. 2008 cited in Campbell et al 2009) the remainder of the world's food supply comes from a wide variety of other crops including sorghum, millet, sweet potato, cassava, groundnuts, sugar cane and many different beans (Campbell et al 2009). Adaptation will therefore include the adoption of many of these crops in areas and farms where they were not previously grown (Chatterjee et al. 2005). The most common adaptation strategies used by farmers in South Africa and Ethiopia include the use of different crop varieties (Bryan et al. 2009). Adopting new crops and varieties has also been an important aspect of recovery from extreme events in Zimbabwe (Chigwada 2005 in Campbell et al 2009). Where salinisation is a problem due to rising sea levels or excessive water extraction, the introduction of salt tolerant crops and varieties can help to ensure continued agricultural production (Galvani 2007; Campbell et al 2009).

Further, the use of currently under-utilised crops can help to maintain diverse and more stable agro-ecosystems (Bowe 2007). The use of indigenous and locally adapted plants can enhance the capacity of communities to cope with changing climatic conditions by providing alternative food and income sources that may be better suited to changing conditions (Eriksen 2005; FAO 2007; Campbell et al. 2009). For example, the bambara groundnut, an ancient grain legume grown, cooked, processed and traded mainly by subsistence women farmers in sub-Saharan Africa, has great potential to provide continued production in the face of growing climate variability (Azam-Ali 2007 cited in Campbell et al. 2009). Also, developing climate-tolerant crop varieties and genotypes, such as those tolerant to drought, heat stress, disease and saline conditions, is another avenue for increasing the adaptive capacity of farmers (Kesavan and Swaminathan 2006 cited in Campbell et al. 2009; Aggarwal
2008; Ortiz et al. 2008 cited in Campbell et al. 2009). Such selection will often depend on locally used varieties and crop wild relatives as sources of characteristics that contribute to drought or flood tolerance or the ability to withstand highly variable climate (Bailey-Serres and Voesenek 2008; Campbell et al. 2009).

\subsection{Changes in Agricultural Practice}

Changing many different aspects of farming practice, ranging from planting and harvest dates to water and soil management practices, will also be an important part of most agricultural adaptation strategies. In many cases alterations to planting and/or harvest dates are helpful in dealing with climatic changes (Rosenzweig and Tubiello 2007; Bryan et al. 2009). The success of changes to cropping dates is also dependent on the availability of pollinators and therefore on changes to biodiversity within the surrounding landscape. Early sowing has been found to be helpful in some cases, though it can be problematic if conditions are dry (Campbell et al 2009). Double cropping may even be possible in regions where the length of the growing season is increased due to climate change. However, such management practice is likely to increase the use of pesticides and fertilizers (Campbell et al 2009).

Managing water supplies and demands will be vital to adaptation of agriculture worldwide, and especially in drylands (Falkenmark and Rockstrom 2008). Water conservation is particularly important in Africa as the majority depend on rainfed agriculture, making watershed development through soil and water conservation vital for adaptation to climate change ( Chatterjee et al. 2005). The use of water-efficient and/or perennial crops can reduce demand for water (Bell et al. 2008; Reid et al. 2007). Also inexpensive measures to enhance water productivity of agricultural systems through soil and watershed conservation can improve rural incomes and diversify livelihood streams whilst increasing carbon sequestration (Castillo et al. 2007; Hartmann, Hediger and Peter 2007; Molden 2007; Noble 2007). For example, in Senegal, where farmers have had to adapt to successive droughts and a drying climate, planting dense perennial hedges as windbreaks helps to improve the microclimate for crop growth (Campbell et al. 2009)

\section{Conclusions}

For centuries humans have altered the natural environment through agricultural practices, largely by converting forests to cultivated areas (Goudie 2000 cited in Hannerz and Lotsch, A. 2006). With continuing agricultural expansion, growing populations especially in developing world and modern agricultural technology of the developed world and food production has increasingly affecting natural and human systems (Foley et al. 2005; Ingco \& Winters 2004 in Hannerz $\mathrm{F}$ and Lotsch A, 2006).

A rich body of research shows the effects of agricultural 
activity on the water cycle, including water quality and quantity (Tilman et al. 2001; Postel et al. 1996; Rockström \& Barron 2005 cited in Hannerz F and Lotsch A, 2006); biodiversity (Green et al. 2005 cited in Hannerz F and Lotsch A, 2006); regional climate circulation (Zeng et al. 1999 cited in Hannerz F and Lotsch A, 2006); and land quality (George $\&$ Nachtergaele 2002). For many African countries agriculture will remain an important engine for economic development for decades to come, and the livelihood of rural populations and the welfare of entire continent critically depend on agricultural productivity. At the same time, agricultural practices have enormous consequences for natural systems and threaten the natural resource endowment in many regions (Hannerz $\mathrm{F}$ and Lotsch A, 2006).

The risks associated with climate change lie in the interaction of several systems with many variables that must be collectively considered. Agriculture (including crop agriculture, animal husbandry, forestry and fisheries) is now held as likely activity that can affect climate, one of the components of the environment. Climate in turn affects agriculture, the source of all food consumed by human beings and domestic animals (Sombroek and Gommes 1996). It must be further considered that not only climate may be changing, but that human societies and agriculture develop trends and constraints of their own which climate change impact studies must take into consideration. Some of the potential problems related to agricultural production include the direct effects of changing hydrological, pedological and plant physiological processes on agricultural production (Sombroek and Gommes 1996).

Despite all these adaptations options, the viability of the many different options available for adaptation in agriculture is dependent on the availability of financial, human and natural resources and on the willingness of farmers to consider the options (Reidsma 2007; Brondizio and Moran 2008). To date, there have been few examples of policy level decisions to promote adaptation in the agriculture sector (Ziervogel et al. 2008). One of the challenges for adaptation researchers is to understand how best to address the information needs of policy-makers and report and communicate agronomic research results in a manner that will assist the development of food systems adapted to climate change (Gregory et al. 2008; Bryan et al. 2009). It has been suggested that adaptation strategies should invest in sustainable agriculture, promoting soil and water conservation and preserving biodiversity and should be part of a strategic governmental response (Leavy and Lussier 2008; Bryan et al. 2009; Campbell et al 2009)

Global climate change, which is currently threatening natural and human systems, will definitely, undermining the productivity of agricultural sector (Collier et al. 2008). Most mechanisms, and two-way interactions between agriculture and climate, are known, even if not always well understood (Sombroek, and Gommes 1996). Generally, improving our understanding of the ecosystem services provided by agricultural biodiversity and of how these may be affected by climate change will be a key element in the development of place-based sustainable agricultural responses to climate change. Responses will need to be dynamic given the complex changes occurring at different scales (FAO 2008).

Smallholder and subsistence farmers' and lor pastoralists are likely to suffer mainly from localized impacts of climate change. These vulnerable communities are among those most dependent on biodiversity and on the provision of ecosystem services to guarantee their livelihoods and well-being. However, there are claims that postulate that local and indigenous communities adapt to change continuously, and agricultural biodiversity, especially crop and livestock diversity, has traditionally formed an important element of farmer risk management strategies. Hence, strengthening farmer adaptation strategies, their ecological knowledge and local institutions will enable development of more effective adaptation strategies to climate change. It will also allow farmers and rural communities to play a role in climate change discussions, decision making and policy formulation. Developing local response strategies will depend on the complementary knowledge of farmers and researchers (FAO 2008).

\section{REFERENCES}

[1] African Union and NEPAD (2003), African agriculture development details programme

[2] Andrew J. Challinor, Frank Ewert, Steve Arnold, Elisabeth Simelton and Evan Fraser (2009) Crops and Climate Change: Progress, Trends, and Challenges in Simulating Impacts and Informing Adaptation. Vol. 60 No. 10, pg 2775-2789 In Journal of Experimental Botany, London-Oxford University Press

[3] Azam-Ali, S. (2007)Agricultural diversification: The potential for underutilised crops inAfrica's changing climates. Rivista di Biologia-Biology Forum, 100, 27-37.

[4] Bailey-Serres, J. and Voesenek, L.A. C. J. (2008) Flooding stress:Acclimations and genetic diversity. Annual Review of Plant Biology, 59, 313-339.

[5] Batima, P., B. Bat, L. Tserendash, S. Bayarbaatar, S. Shiirev-Adya, G. Tuvaansuren, L. Natsagdorj and T. Chuluun, 2005: Adaptation to Climate Change, Vol. 90,ADMON Publishing, Ulaanbaatar.

[6] Bowe, C. (2007) Potential answers to the adaptation to and mitigation of climate change through the adoption of underutilised crops. Tropical Agriculture Association Newsletter, 27, 9-13.

[7] Brooks, N.,W.N. Adger and P.M. Kelly, (2005): The Determinants of Vulnerability and Adaptive Capacity at the National Level and Implications for Adaptation. Global Environ. Change, Vol. 15, 151-163.

[8] Bryan, E., Deressa, T. T., Gbetibouo, G.A. and Ringler, C. (2009) Adaptation to climate change in Ethiopia and South Africa: options and constraints. Environmental Science and Policy, 12, 413-426. 
[9] Campbell,A., Kapos, V., Scharlemann, J. P.W., Bubb, P., Chenery, A., Coad, L., Dickson, B., Doswald, N., Khan, M. S. I., Kershaw, F. and Rashid, M. (2009). Review of the Literature on the Links between Biodiversity and Climate Change: Impacts, Adaptation and Mitigation. Secretariat of the Convention on Biological Diversity, Montreal. Technical Series No. 42, 124 pages.

[10] Challinor AJ, Wheeler TR, Garforth C, Craufurd P, Kassam A. 2007. Assessing the vulnerability of food crop systems in Africa to climate change. Climatic Change 83, 381-399.

[11] Chambwera, M and MacGregor, J (2009) Cultivating Success: The Need to Climate -Proof Tanzanian agriculture. International Institute for Environment and Development.

[12] Chatterjee, K., Chatterjee,A. and Das, S. (2005) Case study 2: India community adaptation to drought in Rajasthan. Ids Bulletin-Institute of Development Studies, 36, 33-52

[13] Collier, P., Paul Collier* Gordon Conway, and Tony Venables (2008). Climate Change and Africa: Oxford Review of Economic Policy Vol. 24 No. 2 pg 337-353; London-Oxford University Press.

[14] Delgado, C.L., N. Wada, M.W. Rosegrant, S. Meijer and M. Ahmed, 2003: Fish to 2020 - Supply and Demand in Changing Global Markets. Jointly published by the International Food Policy Research Institute (IFPRI) and World Fish Centre.

[15] Deressa, T.T (2006) Measuring the Economic Impact of Climate Change on Ethiopian Agriculture: Ricardian Approach. CEEPA Discussion Paper No. 25 School of Forestry and Environmental Studies, Yale University

[16] Eakin, H. and M.C. Lemos, 2006: Adaptation and the state: Latin America and the challenge of capacity-building under globalization. Global Environ. Change, Vol. 16, PP. 7-18.

[17] Easterling, W.E., P.K. Aggarwal, P. Batima, K.M. Brander, L. Erda, S.M. Howden, A. Kirilenko, J. Morton, J.-F. Soussana, J. Schmidhuber and F.N. Tubiello, 2007: Food, fibre and forest products. Climate Change 2007: Impacts, Adaptation and Vulnerability. Contribution of Working Group II to the Fourth Assessment Report of the Intergovernmental Panel on Climate Change, M.L. Parry, O.F. Canziani, J.P. Palutikof, P.J. van der Linden and C.E. Hanson, Eds., Cambridge University Press, Cambridge, UK, 273-313.

[18] FAO. 2007. The State of the World's Animal Genetic Resources for Food and Agriculture. Rome (Italy).

[19] Fischer, G., Shah, M., and Velthuizen, H. (2002). Climate change and agricultural vulnerability. International Institute for Applied Systems Analysis (IIASA).

[20] Fischlin, A., G.F. Midgley, J.T. Price, R. Leemans, B. Gopal, C. Turley, M.D.A. Rounsevell, O.P. Dube, J. Tarazona, A.A. Velichko, 2007: Ecosystems, their properties, goods, and services. Climate Change 2007: Impacts, Adaptation and Vulnerability. Contribution of Working Group II to the Fourth Assessment Report of the Intergovernmental Panel on Climate Change, M.L. Parry, O.F. Canziani, J.P. Palutikof, P.J. van der Linden and C.E. Hanson, Eds. Cambridge University Press, Cambridge, page 213.

[21] Food and Agriculture Organisation (FAO) (2008) Climate Change and Biodiversity for Food and Agriculture, Rome-FAO
[22] George H \& Nachtergaele FO, 2002. Global land use databases. In Tateishi R \& Hastings D (eds), Global Environmental Databases - Present Situation; Future Directions, Volume 2 (pp. 55-67). ISPRS, Geocarto International, Hong Kong.

[23] Hannerz, F and A. Lotsch (2006) Assessment of Land Use and Cropland Inventories For Africa. Pretoria, Centre for Environmental Economics and Policy in Africa (CEEPA)

[24] Harrison, M., 2005: The development of seasonal and inter-annual climate forecasting. Climatic Change, 70, 210-220.

[25] International Institute for Sustainable Development (IISD) (2003) Livelihoods and Climate Change: Manitoba, IISD

[26] IPCC (2002) Climate Change and Biodiversity. IPCC Technical Paper V. The IPCC Working Group II Technical Support Unit.

[27] IPCC, 2007: Summary for Policymakers. In: Climate Change 2007: Impacts, Adaptation and Vulnerability. Contribution of Working Group II to the Fourth Assessment Report of the Intergovernmental Panel on Climate Change, Cambridge University Press, Cambridge, UK.

[28] Kurukulasuriya, P and Mendelsohn, R (2006) A Ricardian Analysis of the Impact of Climate Change on African Crop Land. CEEPA Discussion Paper No. 8

[29] Kurukulasuriya, P. and Rosenthal, S. (2003). Climate change and agriculture: a Review of Impacts and adaptations Agriculture and Rural development Department, Paper No. 91. World Bank, Washington

[30] Leavy, J. and Lussier, K. (2008) The Time is Now: Lessons from FarmersAdapting to Climate Change. Action Aid, South Africa.

[31] Leff, B., N. Ramankutty and J.A. Foley, 2004: Geographic Distribution of Major Crops Across the World. Global Biogeochem. Cy., Vol.18, GB1009.

[32] Luo, Q., Bellotti,W.,Williams,M. andWang, E. (2009) Adaptation to climate change of wheat growing in South Australia: Analysis of management and breeding strategies. Agriculture Ecosystems and Environment, 129, 261-267.

[33] Machiara P, 2004. Kenya. Gateway to land and water information: Kenya National Report. FAO (Food and Agriculture Organization).

[34] McCarthy J, Canziani OF, Leary, NA, Dokken DJ \& White C (eds), 2001. Climate Change 2001: Impacts, Adaptation, and Vulnerability. Contribution of Working Group II to the third assessment report of the Intergovernmental Panel on Climate Change. Cambridge: Cambridge University Press.

[35] Mendelsohn, R and Dinar, A (2005) Climate Change, Agriculture and Developing Countries. Does Adaptation Matter? The World Bak Vol. 14 No.02 Pp 277-293

[36] Millennium Ecosystem Assessment, 2005. Ecosystems and Human Well-being: Biodiversity Synthesis. World Resources Institute, Washington, DC

[37] Olesen, J.E. and M. Bindi, 2002: Consequences of Climate Change for European Agricultural Productivity, Land Use and Policy. European Journal of Agronomy., Vol. 16, Pgs. 239-262. 
[38] Pearce D et al., 1996. The social costs of climate change: Greenhouse damage and benefits of control. In Bruce J, Lee H \& Haites E (eds), Climate Change 1995: Economic and Social Dimensions of Climate Change. Cambridge: Cambridge University Press, pp.179-224.

[39] Porter, J.R. and M.A. Semenov, (2005): Crop Responses to Climatic Variation. Philos. T. Royal Soc. B, Vol. 360, 2021-2035.

[40] Reilly, J (1999) Climate Change and Longrun Agricultural Production. Agricultural Adaptation to Climate Change/AER-740

[41] Rosenzweig, C. and Tubiello, F. (2007)Adaptation and mitigation strategies in agriculture: an analysis of potential synergies. Mitigation and Adaptation Strategies for Global Change, 12, 855-873.

[42] Salazar, L. F., Nobre, C.A. and Oyama,M. D. (2007) Climate change consequences on the biome distribution in tropical South America. Geophysical Research Letters, Vol. 34, L09708.

[43] Seo, S.N and Mendelsohn, R (2006) Climate Change Impacts On Animal Husbandry In Africa: A Ricardian Analysis. CEEPA discussion Paper No. 9. School of Forestry and Environmental Studies, Yale University

[44] Smith, P., D. Martino, Z. Cai, D. Gwary, H. Janzen, P. Kumar, B. McCarl, S. Ogle, F. O’Mara, C. Rice, B. Scholes, O. Sirotenko, 2007: Agriculture. In Climate Change 2007: Mitigation. Contribution of Working Group III to the Fourth Assessment Report of the Intergovernmental Panel on Climate Change [B. Metz, O.R. Davidson, P.R. Bosch, R. Dave, L.A. Meyer (eds)], Cambridge University Press, Cambridge, United Kingdom and New York, NY, USA.

[45] Source: Jarvis, et al.( 2008): The effects of climate change on crop wild relatives, Agric Ecosyst Environ

[46] Thomas, C. D., Bodsworth, E. J.,Wilson, J. D., Simmons,A. D., Davies, Z. G.,Musche,M. And Impacts of climate change on biodiversity Conradt, L. (2001) Ecological and evolutionary processes at expanding range margins. Nature,
$411,577-581$.

[47] Tingem,M. , M. Rivington and G. Bellocchi (2009) Adaptation Assessments for Crop Production in Response to Climate Change in Cameroon. Agronomy for Sustainable Development, Vol. 29 pgs. 247-256

[48] United Nations Environmental Programme (2007). Global Environment Outlook. GEO 4: environment for development. United Nations Environment Programme.

[49] Vasquez-Leon, M., C.T.West and T.J. Finan, 2003:A Comparative Assessment of Climate Vulnerability: Agriculture and Ranching on Both Sides of the US-Mexico border. Global Environ. Change, Vol. 13, 159-173.

[50] Wheeler, T.R., P.Q. Crauford, R.H. Ellis, J.R. Porter and P.V. Vara Prasad, 2000: Temperature Variability and the Yield of Annual Crops. Agriculture, Ecosystem and Environment Vol. 82, Pgs. 159-167.

[51] Wollenweber, B., J.R. Porter and J. Schellberg, 2003: Lack of Interaction Between Extreme High-Temperature Events at Vegetative and Reproductive Growth Stages in Wheat. J. Agron. Crop Sci., Vo. 189, 142-150.

[52] Yanda, P.Z., Majule, A.E. and Mwakaje, A.G. (2005): Implications of Farming Practices on the Environment, Food Security and Poverty Levels in Matengo Highlands, Mbinga District, Southern Tanzania. IJEE, Vol. IV, No. 1. P.55-80.

[53] Yohe, G. and R.S.J. Tol, 2001: Indicators of social and economic coping capacity: moving toward a working definition of adaptive capacity. Global Environ. Change, 12, $25-40$.

[54] Zheng, Y.Q., G. Yu, Y.F. Qian, M. Miao, X. Zeng and H. Liu, (2002): Simulations of Regional Climatic Effects of Vegetation Change in China. Q. J. Roy. Meteor. Soc., 128, 2089-2114, Part B.

[55] Ziervogel, G., Cartwright,A., Tas,A.,Adejuwon, J., Zwemoglio, F., Shale,M. and Smith, B. (2008) Climate Change and Adaptation in African Agriculture. Stockholm Environment Institute, Sweden. 